\title{
Rethinking Legal Research on Matters of International Police Cooperation: Issues, Methods and Raison d'Être
}

\author{
Giulio Calcara ${ }^{1}$ \\ Published online: 26 August 2019 \\ (c) The Author(s) 2019
}

\begin{abstract}
On a daily basis, police services from countries with different legal traditions and diverse criminal justice systems exchange legal documents and criminal intelligence for the purpose of tackling transnational and international crime or to locate individuals. This is international police cooperation in a nutshell, an articulated phenomenon riddled with complexities and legal challenges. And yet, when compared with other fields, international police cooperation is an area of research traditionally overlooked by legal scholars, practitioners, and experts alike. This article wants to stimulate a reflection on what is, or should be, the role and the nature of legal research in the field of international police cooperation. This article does not aim to be comprehensive, nor to provide a definitive guide on how to conduct legal research. Instead, it focuses on what aspects of legal research can be beneficial for the study and the betterment of international police cooperation.
\end{abstract}

Keywords Legal research · International police cooperation · Methodology · INTERPOL · Human rights

\section{Introduction}

On a daily basis, police services from countries with different legal traditions and diverse criminal justice systems ${ }^{1}$ exchange legal documents and criminal intelligence for the purpose of tackling transnational and international crime or to locate individuals. ${ }^{2}$ Information and documents exchanged can range from police tips to enforceable arrest warrants. ${ }^{3}$ They are often exchanged through international entities, such as INTERPOL, or regional ones, such as AFRIPOL, Europol, and Law Enforcement Cooperation Program (LECP). This exchange can be performed on a

\footnotetext{
1 Savino (2010).

2 Calcara (2018).

3 Deflem (2009).

Giulio Calcara

giulio.calcara@uef.fi

1 University of Eastern Finland, Law School, Joensuu, Finland
} 
bilateral $^{4}$ or multilateral level. ${ }^{5}$ Needless to say, the exchanged documents can have legal status in some countries, while being void of any legal value in others. ${ }^{6}$ This is the basic nature of international police cooperation. It is an articulated phenomenon riddled with complexities and legal challenges. And yet, if compared with other fields, international police cooperation is an area of research traditionally overlooked by legal scholars, practitioners, and experts alike. ${ }^{7}$

This article wants to stimulate a reflection on what is, or should be, the role and the nature of legal research in the field of international police cooperation. This article does not aim to be comprehensive, which would be a herculean task if all the different practices around the globe were to be taken into account, nor does it aim to provide a definitive guide on how to conduct legal research. Instead, it focuses on what aspects of legal research can be beneficial for the study and the betterment of international police cooperation. In the end, for explanatory purposes, an agenda for legal research on matters of international police cooperation is proposed.

\section{Background}

Since the second half of the previous century there has been a significant and constant increase in the proliferation of transnational criminal activities. Several reasons for this can be pointed out, but among the key factors are the constant development of technology and the increasing ease of travelling. ${ }^{8}$

New challenges have emerged for police services around the globe. The traditional and purely domestic methods of policing have gradually become obsolete when dealing with crime areas of transnational nature such as cybercrime, human trafficking, terrorism, and so forth. For this reason, it has become of utmost importance for police services of different countries to adopt a coordinated response through international cooperation. ${ }^{9}$ In the past, police services of different countries had to cooperate in cumbersome manners, using diplomatic

\footnotetext{
4 Mc Kenzie (2017).

5 Hughes et al. (2013) and Sciarabba and Sullivan (2010).

${ }^{6}$ Gerspacher and Pujas (2013).

7 Bowling and Sheptycki (2015). More than that, legal research is scarce in regard to the study of which laws govern police activities, both on the domestic and the international level.

8 Anderson (1989) and Deflem (2002).

9 Andreas and Nadelmann (2006). This is especially true since international policing exists mainly as a result of international police cooperation, as domestic police services and forces do not possess the capacity of performing traditional policing activities outside their territorial jurisdiction. For the sake of clarity, it should be noted that there are few exceptions to this. For instance, there is the legal framework The Schengen acquis-Convention implementing the Schengen Agreement of 14 June 1985 between the Governments of the States of the Benelux Economic Union, the Federal Republic of Germany and the French Republic on the gradual abolition of checks at their common borders. It allows, under limited and specific circumstances, police services of the contracting parties to conduct cross-border surveillance and transnational hot pursuit. Additionally, it is possible to cite also exceptional cases of international policing missions taking place in the limited context of peace operations, for instance, through the use of the United Nations police (UNPOL). See: Hughes et al. (2013).
} 
channels. This was the case until the creation of major structures of cooperation such as INTERPOL, ${ }^{10}$ and later Europol ${ }^{11}$ and many others, ${ }^{12}$ which nowadays provide safe avenues for police services to communicate directly and around the clock, bypassing the diplomatic hurdles which pose limitations of both time and political character. ${ }^{13}$ However, cooperation can still take place outside these entities, formally or informally, ${ }^{14}$ at the bilateral ${ }^{15}$ or multilateral level. ${ }^{16}$ Evidently, the diversity of approaches makes international police cooperation an extremely complex phenomenon, difficult to be captured into a single clear definition. Indeed, many of the historical definitions often fail to express the complexities posed by modern times. For a long time, international police cooperation has been defined as the specific type of police cooperation happening across national and geo-political borders, for the purpose of exchanging criminal intelligence. ${ }^{17}$ However, if the last thirty years or so are taken into account, such a definition appears to be rather narrow. With this in mind, some scholars have offered new, more encompassing definitions. For instance, Lemieux defines international police cooperation as the: “...intentional or unintentional interaction between two or more police entities (including private and public agencies) for the purpose

\footnotetext{
10 The International Criminal Police Organization (ICPO-INTERPOL) is an international organization with 194 member countries. It is the leading organization in promoting police cooperation on a global scale. The organization's aims are set in Art. 2 of INTERPOL's Constitution, and they are "to ensure and promote the widest possible mutual assistance between all criminal police authorities within the limits of the laws existing in the different countries and in the spirit of the "Universal Declaration of Human Rights", and "to establish and develop all institutions likely to contribute effectively to the prevention and suppression of ordinary law crimes." See: Lemon (2019), Boister (2019), and Martha (2010). For more information, see the official website of INTERPOL: https://www.interpol.int/en.

11 Europol, officially known as The European Union Agency for Law Enforcement Cooperation, is an agency of the EU operating in the field of police cooperation. In addition to Europol, there are a number of other EU agencies involved in police and judicial cooperation, the main ones being the European Union Agency for Criminal Justice Cooperation (Eurojust) and, in the foreseeable future, the European Public Prosecutor's Office (EPPO). The current legal basis of Europol is Regulation (EU) 2016/794. In this legal document, the objectives of Europol are listed in Art. 2, and these are to "... support and strengthen action by the competent authorities of the Member States and their mutual cooperation in preventing and combating serious crime affecting two or more Member States, terrorism and forms of crime which affect a common interest covered by a Union policy, as listed in Annex I. 2. In addition to paragraph 1, Europol's objectives shall also cover related criminal offences..." See: Boister (2019), Nunzi (2006) and Thwaites (2006). For more information, see the official website of Europol, https://www. europol.europa.eu/, and the official website of Eurojust, http://www.eurojust.europa.eu/Pages/home.aspx. More information is also available at: European Parliament (2019a, b).

12 Reference can be made for instance to the various regional entities of police cooperation, such as the African Union Mechanism for Police Cooperation (AFRIPOL), the Police Community of the Americas (AMERIPOL), the Police Organization of the Association of Southeast Asian Nations (ASEANAPOL), and the Gulf Cooperation Council Police (GCC). See: Zabyelina (2019, p. 308).

13 Andreas and Nadelmann (2006).

14 Sadoff (2016).

15 Folami and Naylor (2017).

16 Anderson (1989) and Klosek (1999).

17 Lemieux (2013).
} 
of sharing criminal intelligence, conducting investigations, and ultimately apprehending suspects."18

What can be affirmed with certainty, is that all forms of cooperation can be at times problematic, as many legal and practical issues need to be considered whenever police services of different countries decide to interact among each other. ${ }^{19}$

There are traditional legal issues hampering international police cooperation, which arise from the incompatibility of national laws and criminal justice systems. ${ }^{20}$ The presence of such legal issues can usually lead to two different outcomes. First, police services might decide to desist on activating cooperation processes if differences in substantive criminal law are significant. In general, police cooperation is firmly grounded on the premise of an equivalent criminalization of specific acts or omissions. ${ }^{21}$ Additionally, differences in procedural law can also potentially play a big part in hindering cooperation. Second, police services might circulate, knowingly or unknowingly, documents which possess legal status in some countries, while being void of any legal value in others. ${ }^{22}$ Due to structural factors, the latter outcome is more likely to occur whenever cooperation is carried out through complex multilateral structures of cooperation, such as INTERPOL.

Furthermore, there are intentional cases of misuse of international police cooperation entities, mostly carried out by countries who use police cooperation as means to track dissidents outside their borders. ${ }^{23}$ To understand the significance of this phenomenon, it should be pointed out there have been several instances where domestic courts have fabricated evidence to create false charges against political dissidents or non-aligned members of the media in order to demand their extradition. ${ }^{24}$ As a consequence, unlawful arrest warrants and fictional judicial documents have ended up being circulated among unaware police forces of different states. ${ }^{25}$ Evidently, such unsavory practices have the potential of causing violations of human rights. ${ }^{26}$ For example, in the case of Khadzhiev

\footnotetext{
18 Lemieux (2013, p. 1). The term police entities can here be used in reference to both domestic police services and international police cooperation entities. Significantly, while it is evident that police services are different among different countries, even international police cooperation entities tend to differ significantly from each other, both structurally and functionally. For example, INTERPOL is an international organization, albeit being created without treaty, whereas Europol is a European agency. Ling (2010a), Sheptycki (2004) and Europol (2018a). Many other examples can be made when the attention is directed towards other regions of the world. See: Hughes et al. (2013) and Sciarabba and Sullivan (2010).

19 Joutsen (2014).

20 Gerspacher (2008).

21 Andreas and Nadelmann (2006) and Lemieux (2013).

22 Gerspacher and Pujas (2013).

23 Lemon (2019).

24 Calcara (2018) and Savino (2010).

25 Unfortunately, at the moment exact quantitative data concerning cases of misuse or attempted cases of misuse is unattainable. However, the estimates provided by researchers tend to be high in number.This appears to be also confirmed by the increasingly growing number of cases handled by domestic courts, and to a minor extent, by international courts and tribunals. The NGO Fair Trials has been particularly active in gathering information on cases of misuse that have taken place in the context of INTERPOL. See: Fair Trials $(2013,2018)$.

26 Both (2001) and Calcara (2018).
} 
v. Bulgaria, ${ }^{27}$ the European Court of Human Rights reported that Turkmenistan produced false criminal evidence for the sole purpose of incriminating Mr. Khadzhiev in order to obtain his extradition once he had relocated with his family to Bulgaria. In this instance, Turkmenistan asked and obtained INTERPOL to publish a red notice, a type of document which could under certain conditions amount to a proto-international arrest warrant, ${ }^{28}$ against Mr. Khadzhiev. ${ }^{29}$

In addition, the terrorist attacks in the US on 11 September 2001 have caused a significant change in the way police services around the globe interact with each other, exacerbating some problematic aspects which have always characterized cooperation on the international level in matters of policing. As traditional national central control has been partly discarded in search for a more interconnected way to provide security, ${ }^{30}$ some scholars have pointed out the existence of a concerning phenomenon: cooperation has started happening also outside the legal boundaries defined by international agreements. ${ }^{31}$ Particularly relevant is the study conducted by Deflem on how INTERPOL operated following the aftermath of 9/11 in the context of terrorism related criminal offences. ${ }^{32}$

Notwithstanding the significant complexities and several legal challenges, international police cooperation is a topic of legal research that has been largely neglected, especially if compared with other fields. Only in recent years has the topic started to attract a certain degree of attention, surely facilitated by the growing role of INTERPOL in the international scene ${ }^{33}$ and the development of Europol in Europe. ${ }^{34}$ Attention has been given, for example, to the lack of public or political scrutiny in regard to the expansion of INTERPOL, and to the concerning lack of accountability of police cooperation entities in general. ${ }^{35}$ Even Europol, which remains sheltered under the EU umbrella, has not been exempted from criticism, especially in matters of legal accountability. ${ }^{36}$

With a relatively small but ever-growing number of publications in this area, the time has come to assess what should be the nature of legal research and the purpose of conducting such research in the study of international police cooperation. These two points, tightly intertwined, sound deceptively simple, but they surely are not.

\footnotetext{
27 See: Case of Khadzhiev v. Bulgaria App. No. 44330/07, 03/06/2014, ECtHR, Judgment (Merits and Just Satisfaction): http://hudoc.echr.coe.int/eng\#\{"itemid":["001-144351"]\}.

28 Savino (2010) and Sheptycki (2004).

29 While this type of misuse is far from rare, what makes this case particularly significant is the fact that an international court, if only incidentally, addressed the specific content of the INTERPOL's document affirming how the enforcement of the red notice would constitute a violation of human rights. Calcara (2018).

${ }^{30}$ Bowling and Sheptycki (2012), Mitsilegas (2012), Ugelvik (2019) and Wennström (2013).

31 Deflem $(2002,2004 a, b)$.

32 Deflem (2004a, b).

33 Ling (2010a) and Martha (2010).

34 Busuioc et al. (2011).

35 Bowling and Sheptycki (2012).

36 Riekmann (2008).
} 
According to different branches of the academic literature, there are in fact various approaches to legal research, all emphasizing a unique purpose.

\section{Different Approaches to Legal Research}

On a general level, there are two main historical traditions of legal scholarship, which are grounded on two different approaches to legal research: the black-letter law and the law in context. ${ }^{37}$ The differences between these two traditions are firmly rooted in how law should be perceived, approached, and researched.

The black-letter law, also known as the doctrinal tradition, typically views law almost as an independent corpus that is to be considered oblivious from external factors and circumstances. Consequently, critical analysis on the subject of law is "confined to examining the logic or rational coherence of particular legal decisions or areas of law". ${ }^{38}$ It might be of interest to underline how this tradition is closely bound to the school of thought according to which there ought to be a clear border between the science of law and the remaining disciplines. Needless to say, following this tradition blindly has been deemed by the majority of legal scholars to be an old-fashioned and an obsolete way of approaching legal research. ${ }^{39}$ However, the approach can still be useful to facilitate the exegetic work of legal scholars, experts, and practitioners. Significantly, this is true when researching international police cooperation, a point that will be further discussed later.

The law in context, sometimes referred to as the socio-legal approach, is instead more recent. It began to properly flourish between the 1960s and the 1970s. The starting point of this approach is almost diametrically opposite of the previous one. It views the problems in society, and not the law itself, as the ideal starting point for research. Consequently, it has added an extra layer to legal studies. More specifically, the law itself is seen as a social phenomenon. This way of approaching the law is conducive to potentially very different research outcomes. Law could be the solution, or part of the solution, to certain problems, but other non-legal approaches such as political or social re-arrangements might be more appropriate for tackling certain issues. $^{40}$

For the sake of completion, it is useful to point out that there are many other approaches to legal research, such as critical legal studies and feminist legal studies. The list is long. ${ }^{41}$ However, it should also be mentioned that most of these approaches seem to share several essential traits with the socio-legal approach. Defining them would go beyond the scope of this article. Instead, what is crucial to underline, is that the demarcation between the black-letter approach and law in context approach is thinner than it seems. For example, several works that have aspired

\footnotetext{
37 McConville and Chui (2007).

38 Cownie (2004, p. 69).

39 Van Gestel et al. (2017).

${ }^{40}$ Cownie (2004) and McConville and Chui (2007).

41 Cownie (2004).
} 
to mainly consist of doctrinal legal research have ended up giving a lot of information about the context in which the law is formed. Vice versa, several socio-legal works have needed to perform a detailed study on the state of law as a premise, before dealing with the specific object of research. ${ }^{42}$

\section{Legal Research on Matters of Police and Policing}

Before exploring the nature and the purpose of legal research in matters of international police cooperation, it is relevant to note that modern academic research in matters of police and policing, at least the type employing empirical methods of research, can be traced back to the 1950's. ${ }^{43}$ From this, two different areas of research have developed, partly due to the conceptualizations of the two distinct terms of police and policing.

Police research focuses on the study and analysis of agencies mostly identifiable worldwide with terms such as police force or police service. ${ }^{44}$ Consequently, legal research focusing on the police refers mainly to the study of the body of laws governing the structure and the function of such agencies.

Policing research instead focuses on the study and analysis of activities that are traditionally associated with social order and control, regardless the actors involved. ${ }^{45}$ Legal research in matters of policing refers thusly to the research on the body of laws that govern the aforementioned activities.

On a general level, legal research focusing on subjects such as domestic police and domestic policing are typically studies of domestic criminal judicial procedure and domestic police regulations. ${ }^{46}$ More specifically, the research interest mainly tends to revolve around the laws defining concepts such as police discretion, deviance, and accountability. ${ }^{47}$

Police research and policing research have largely evolved throughout the years and trends in both of them have changed, especially since the 1980's. Research tends to focus on various areas of study, such as the search of good practices for police and for efficiency in policing. Consequently, legal research of police and policing have transformed. ${ }^{48}$ This transformation is most likely connected also to the development of the socio-legal studies.

In 2010, Martin Innes suggested that policing research can be ideally divided under two headlines; Mirror and Motor. From the Mirror perspective "police research tries to reflect the complex realities of policing in a globalizing world, seeking to capture and articulate as accurately as possible the complexities of what it

\footnotetext{
42 Cownie (2004).

43 Innes (2010a).

44 Innes (2010a).

45 Brodeur (2010) and Innes (2010a).

46 Hodgson and Roberts (2010).

47 Choongh (2007).

48 Choongh (2007) and Reiner (2000).
} 
is that the police do and how they do it". ${ }^{49}$ From the Motor perspective, "research is deliberately engaged as a motor, an 'engine' for change and improvement". 50 While from the context it appears that the subdivision of Mirror and Motor types of research is meant to mainly explain the diverse processes of researching the concepts of police and policing from the domestic perspective, the same metaphor, with only some minor exceptions, can later shed some light also on the different kinds of legal research on matters of international police cooperation.

\section{Legal Research on Matters of International Police Cooperation}

As mentioned before, legal research on topics such as domestic police and domestic policing focuses mainly on the study of domestic criminal judicial procedure and domestic police regulations. ${ }^{51}$ Essentially, this is true also for legal research on matters of international police cooperation practices, which are essentially an extension of domestic police and domestic policing. However, when researching topics such international police cooperation and entities that are inter alia mandated to promote or perform international police cooperation or international policing in general, another layer of study is required. This is the study of the relevant branches of international law, such as public international law, international human rights law, international criminal law, transnational criminal law, and international institutional law. ${ }^{52}$

Some considerations are in place, as researching international law presents a peculiar set of challenges that need to be addressed. ${ }^{53}$ For instance, it is complicated for researchers, as well as practitioners, to construe a precise hierarchy among at times conflicting legal sources. Although from Article 38(1) of the Statute of the International Court of Justice it is possible to infer a hierarchy, often this is of no avail, due to the issue referred to as disorder of orders. This phenomenon is a common side effect of the existence of a plurality of legal norms. The situation is typical in international law, where there are simultaneously "horizontal and vertical connections between legal systems and other legal or non-legal normative systems". 54 At times, the disorder of orders makes it hard to understand what legal framework is to be taken into account when researching a specific topic. Another major issue

\footnotetext{
49 Innes (2010b, p. 128).

50 Innes (2010b, p. 128).

51 Hodgson and Roberts (2010).

52 For researching international institutional law, which is on its own a relatively recent and multifaceted field of legal research, a solid theoretical framework is provided by Klabbers and Wallendahl (2011). Research Handbook on the Law of International Organizations. Helsinki: Edward Elgar Publishing. One of the most comprehensive studies on police cooperation, albeit at the EU level, from the perspective of institutional dynamics is provided in Occhipinti (2015). "Still moving toward a European FBI? Re-examining the politics of EU police cooperation." Intelligence and National Security 30(2-3): 234-258. The article is essentially a continuation of previous work by the same author, titled: Occhipinti (2003). The politics of EU police cooperation: toward a European FBI?. London: Lynne Rienner Publishers, 2003.

53 Hall (2007).

54 Cryer et al. (2011, p. 22).
} 
affecting the research of international cooperation is the fragmentation of international law. This has been explored in detail by Koskenniemi and Leino. ${ }^{55}$

Now it is time to consider different approaches to legal research for international police cooperation and, perhaps more importantly, to reflect on the purpose and opportunities of conducting legal research in this area. An agenda for legal research is hereafter proposed for explanatory purpose, and the relevant methodological approaches are suggested.

The agenda for legal research can be devised on the basis of three thematic areas:

1. To research what are the laws governing international police cooperation.

2. To evaluate the various draw-backs of the common methods of international police cooperation, and to assess how/whether it is possible to eliminate, or at least, limit them.

3. To postulate different methods of cooperation leading to more efficient practices.

Before addressing each thematic area separately, few general preliminary remarks should be provided. If the previously mentioned metaphor of Innes about the division of policing research under the headlines of Mirror and Motor is taken into account, it can be observed that the first thematic area of the agenda resembles the Mirror category of research, while the second and the third area are similar with the Motor category. The third thematic area is the most complex one of the three since it is open-ended and multifaceted. Furthermore, if compared to the first two, the third area is a secondary object of research. It is in fact ontologically subordinate to a thorough research and exploration of the first two thematic areas.

\section{The First Thematic Area}

Concerning the first thematic area, "to research what are the laws governing international police cooperation", research can be conducted according to a blueprint provided by the doctrinal approach, which, as previously stated, is interested in ascertaining the state of the law. ${ }^{56}$ This kind of research has an exegetic purpose, which is to shed light on how the different aspects of the cooperation process are regulated. Only after this it will become feasible to perform assessment or provide critique. As such, this kind of research is usually the premise of further research. However, it clearly possesses an essential autonomous purpose as well.

At first glance, research fitting into this thematic area may appear redundant. However, it is crucial to consider how international police cooperation suffers from the previously mentioned issues of disorder of orders ${ }^{57}$ and fragmentation of laws. ${ }^{58}$ Different systems of cooperation co-exist, ${ }^{59}$ connecting police systems of countries that are again

\footnotetext{
55 Koskenniemi and Leino (2002).

56 Cownie (2004).

57 Cryer et al. (2011).

58 Koskenniemi and Leino (2002).

59 Gerspacher (2008).
} 
in turn tied to their domestic criminal judicial procedures and legislations. A simple example can clarify this complex issue: when a police service of a European country decides to cooperate with its counterpart of another European country, it has the possibility of activating cooperation through several avenues, the principal ones being INTERPOL and Europol. Yet, it can also decide to cooperate on a bilateral level or, depending on the crime that is the object of cooperation, through other less definableat least from the legal perspective-forms of cooperation. ${ }^{60}$ Aside from the bilateral level, the other methods of cooperation are processed through entities that are governed by specific set of regulations and are to be utilised according to different set of legal procedures, unwritten practices, and modi operandi. Furthermore, police services of EU countries need to be obedient of EU law and their respective domestic criminal judicial procedures. Thus, it is apparent that the question of what laws govern international police cooperation is not an easy one to answer.

Further, this area of research can be in turn dissected into (at least) three subsections, each of great interest:

1. Which laws are involved during cooperation.

2. What are the legal powers of the actors involved (e.g. the legal powers of the police services of the countries involved in the cooperation)

3. What are the rights of the individuals who are affected by the outcome of cooperation.

As mentioned, all these subsections can be approached through traditional doctrinal legal research. A good example of this kind of research is the seminal work of Martha on the legal foundations of INTERPOL, which manages to address all three subsections. ${ }^{61}$

However, by adopting other approaches to legal research, such as the socio-legal one, researching the laws that govern international police cooperation can have a very different function. For instance, Sheptycki affirmed how "Interpol is but one element of a vast transnational legal order that has no democratic basis and which needs to be progressively uncovered through piecemeal empirical case studies." 62 Consequently, Sheptycki postulated that by researching INTERPOL and the laws governing it, researchers can obtain valuable insight into how law develops under transnational conditions. While this type of research might not have an immediate application for the improvement of international police cooperation, it is still of great value as it provides a key to understanding and predicting changes in law in this field and beyond. ${ }^{63}$

\footnotetext{
${ }^{60}$ A good example of this last instance could be cooperation processes activated through the Virtual Global Taskforce on matters of Cybercrime. See: Reitano et al. (2015).

61 Martha (2010).

62 Sheptycki (2017, p. 65).

63 In this paragraph it is shown how legal research on matters of international police cooperation can be approached by following both the doctrinal and the socio-legal approach, according to the specific object of interest. That is not something new nor unusual in the realm of legal research. On the contrary, it is quite common to explore concepts or institutions under different parameters. Cardwell and Hervey (2016).
} 


\section{The Second Thematic Area}

In regard to the second thematic area, "to evaluate the various draw-backs of the common methods of international police cooperation, and to assess how/whether it is possible to eliminate, or at least, limit them." reference can be made to the frequent violations of human rights, an area in which INTERPOL unfortunately has an alarming record. ${ }^{64}$ In general, all cases of intentional or unintentional misuse of INTERPOL and Europol, or any other international police cooperation entity and operation could be used as an example. If compared to the first thematic area, in the second area a more operative intent is required, as the role of the researcher is essentially to find solutions to the aforementioned issue.

To continue using the cases of misuse of INTERPOL as an example, it is crucial to investigate whether possibilities of appeal offered to individuals against legal documents produced or circulated by INTERPOL are fair and sufficient. To be precise, research needs to focus on what are the possibilities of an individual who is being sought after through INTERPOL's red notices or diffusions to appeal and/or redress. ${ }^{65}$ Further, what kind of legal safeguards does INTERPOL have in place to prevent cases of misuse, and whether they are adequate and ample. ${ }^{66}$

The examination of the possibilities of a private person to appeal against acts, actions, or omissions of an international organization is not a new area of research.$^{67}$ What can be problematic, and certainly worthy of additional explorative studies, is that police cooperation does not always take place trough INTERPOL (or other cooperation organizations). At times it is conducted on the bilateral or multilateral level ${ }^{68}$ through platforms which are not easily identifiable from the legal perspective.

Another issue afflicting this type of legal research arises from the difficulty of striking a balance between two, at times conflicting goals. The first goal is to protect the rights of individuals and fulfil the requirement for procedural justice. ${ }^{69}$ The second goal is to warrant safety. ${ }^{70}$ The balance between these two goals epitomizes the paradox of international police cooperation on several levels. It comes natural to reflect once again on INTERPOL, where police services of different states, with at times extremely different legal traditions and criminal justice systems, have to cooperate to tackle criminal activities. ${ }^{71}$ These circumstances make intentional and unintentional misuse of the system to be a rather common and expected side effect, often at the expense of rights of individuals. Further, some states involved in the organization are known for purposely abusing the system to persecute dissidents outside their

\footnotetext{
${ }^{64}$ Both (2001) and Fair Trials (2013, 2018).

${ }^{65}$ Ling (2010b), Martha (2010) and Savino (2010).

${ }^{66}$ Calcara (2018), Savino (2010).

${ }^{67}$ Wellens (2002).

${ }^{68}$ Hughes et al. (2013) and Sciarabba and Sullivan (2010).

69 Bottoms and Tankebe (2017).

70 Ashworth (2002).

${ }^{71}$ Savino (2010).
} 
borders. ${ }^{72}$ Yet, their cooperation with others is necessary, a necessary evil if you wish, pending the risk of creating safe havens for transnational criminal organizations. ${ }^{73}$ Such complex state of affairs demands a deep reflection.

\section{The Third Thematic Area}

The third thematic area, "to postulate different methods of cooperation leading to more efficient practices", is regrettably still a largely unexplored area of research. As such, the scope of the research can be interpreted in various ways.

From one point of view, this thematic area includes the type of research dedicated to the improvement of the current systems of cooperation. This can be achieved, for example, by comparing different systems of cooperation across the globe in order to study which practices are most efficient. In legal studies, this type of research is fairly common, and it is usually conducted by adopting the method of comparative law. ${ }^{74}$ Here, inspiration is drawn from one legal system to foster reform of law in another. ${ }^{75}$ When applied in the context of international cooperation, the legal frameworks governing practices of police cooperation in several different areas can be compared to establish the ones conducive of the best outcomes. Naturally, the comparison needs to be done in awareness of the context in which practices and legal frameworks operate. ${ }^{76}$ This is by no means an easy task, as several factors need to be taken into account whenever approaching concepts such as legal transplants. One of the most significant factors is the relationship between law and culture. ${ }^{77}$ The concept of culture can be viewed as culture in general, for instance, in a nation, or culture within an entity, for example, culture in a domestic police force. In this specific case, it could be wise to appreciate the specific police environment and the different local needs for policing. Yet, many other factors could and should be taken into account.

On the other hand, research of this thematic area can be daring, directed towards a holistic rethinking of the current ways of conducting cooperation. Legal research has the potential to be used as means to postulate the development of new paradigms for cooperation. Thus, one role of the researcher is to predict arising needs for cooperation and to propose feasible legal ways to meet these needs. For instance, in the immediate future a crucial area of research is bound to be the development of sophisticated forms of judicial cooperation on the international level. This need has been voiced for a very long time, ${ }^{78}$ but it has yet largely remained unaddressed. Concerning this, questions can arise whether new and separate systems of cooperation

\footnotetext{
72 Both (2001)and Fair Trials (2013, 2018).

73 Calcara (2018). Unsurprisingly, similar considerations were made by other researchers in similar fields regarding international cooperation. See: Jackson and Summers (2012).

74 Bogdan (1994) and Zweigert and Kötz (1998).

75 Weigend (2006).

76 See for instance the outstanding work of Jung and Lee on a police cooperation model in Southeast Asia and the examination concerning its global application. See: Jung and Lee (2019).

77 Watt (2012).

78 Chang (1994).
} 
should be devised, or if the current systems could gradually expand their range of function in order to encompass this new task. In synthesis, is it conceivable to create one singular entity in charge of promoting cooperation across the globe among all actors involved in the criminal justice system, from police services to prosecutors and judges. ${ }^{79}$ In the past, this has been hinted by researchers especially with reference to INTERPOL. ${ }^{80}$

Now to sum up with few concluding remarks. In this exploration of the three thematic areas forming the agenda for legal research, attention was mostly given to traditional approaches to legal research. However, it is crucial to account for the wishes and expectations of the actors involved in cooperation processes, ${ }^{81}$ namely police officers, police services, and international police cooperation entities. Insight could and should be gained by gathering diverse data through interviews and, whenever feasible, through other ethnographic research methods. ${ }^{82}$ Additionally, valuable information can be obtained from reports and studies regularly published by those same actors in charge of facilitating the cooperation processes. ${ }^{83}$

\section{Conclusions}

In this chaotic time, riddled with heinous forms of transnational and international crime, it is paramount for police forces and services to interact on a global level in a consistent way. The way of conducting cooperation is changing constantly, and it shapes and is at the same time shaped by the international community.

Since the train of globalization is rapidly moving forward, it is not an exercise in futility to attempt to predict what kind of drastic changes will occur in the near future.

\footnotetext{
79 On this matter, the European Union presents some interesting blueprints. Particularly worthy of consideration, is the kind of cooperation carried out through Joint Investigation teams (JITs). JITs are purpose specific international cooperation tools created through an agreement among members of judicial and police institutions of two or more states. They are created as a way of conducting joint investigations in a limited amount of time. Even though they were developed in the European context (originally mentioned in the 1997 Amsterdam Treaty, currently based in the EU Mutual Legal Assistance Convention and the 2002 Framework Decision on JITs), JITs can involve countries outside the EU, if allowed by the presence of relevant legal documents. This makes JITs de facto truly international tools, albeit limited in time and purpose. One of the pioneer operations conducted with a non-EU member state (the former Yugoslav Republic of Macedonia), was a project called JIT Vineyard, which involved a large drug trafficking case. European agencies such as Eurojust and Europol can provide support to the JITs. Being the judicial cooperation body of the EU, Eurojust in particular has a key role. Among its many functions, the agency can provide tools and resources in the operation phases, in order to overcome those practical and legal issues which might present over the course of the JITs activities. See: Boister (2019), Europol (2019) Synnøve (2019), and General Secretariat of the Council (2014, 2017).

80 Savino (2010).

81 Bayens and Roberson (2011).

82 Marks (2004).

83 Fitting examples could be the annual reviews, the "EU Terrorism Situation \& Trend Report (Te-Sat)", the "Serious and Organised Crime Threat Assessment (SOCTA)", and the "Internet Organised Crime Threat Assessment (IOCTA)" published by Europol, or the annual reports of INTERPOL. See: Europol (2017, 2018b, 2019), INTERPOL (2018).
} 
This article provides a reflection and a basic agenda on what kind of legal research can be beneficial for studying, analysing, and, conceivably improving international police cooperation. As it is illustrated, international police cooperation is a relatively unique and overlooked area of legal research. More active involvement of the academic community in this discourse is vital to kindle and provide understanding, and ultimately to work towards the elimination of the legal issues hampering cooperation. Innes expressed how research in policing is most fruitful when police and researchers work in unison. ${ }^{84}$ For this reason, it is vital that both the police and the academia reach towards each other to study, discuss, and device improvements to the legal frameworks governing cooperation.

Acknowledgments Open access funding provided by University of Eastern Finland (UEF) including Kuopio University Hospital.

\section{Compliance with Ethical Standards}

Conflict of interest The author declares that he has no competing interests.

Open Access This article is distributed under the terms of the Creative Commons Attribution 4.0 International License (http://creativecommons.org/licenses/by/4.0/), which permits unrestricted use, distribution, and reproduction in any medium, provided you give appropriate credit to the original author(s) and the source, provide a link to the Creative Commons license, and indicate if changes were made.

\section{References}

Anderson, Malcom. 1989. Policing the World: Interpol and the Politics of International Police Cooperation. New York: Oxford University Press.

Andreas, Peter, and Ethan Nadelmann. 2006. Policing the Globe: Criminalization and Crime Control in International Relations. New York: Oxford University Press.

Ashworth, Andrew. 2002. Human Rights, Serious Crime, and Criminal Procedure. London: Sweet \& Maxwell.

Bayens, Gerald J., and Cliff Roberson. 2011. Criminal Justice Research Methods: Theory and Practice. Boca Raton: CRC Press.

Bogdan, Michael. 1994. Comparative Law. Deventer: Kluwer.

Boister, Neil. 2019. An Introduction to Transnational Criminal Law. New York: Oxford University Press.

Both, Charles R. 2001. International Police Force or Tool for Harassment of Human Rights Defenders and Political Adversaries: Interpol's Rift with the Human Rights Community. ILSA Journal of International and Comparative Law 8: 357-362.

Bottoms, Anthony E., and Justice Tankebe. 2017. Police Legitimacy and the Authority of the State. In Criminal Law and the Authority of the State, ed. Antje Du Bois-Pedain, Magnus Ulväng, and Petter Asp. Oxford: Hart Publishing.

Bowling, Ben, and James Sheptycki. 2012. Global Policing. London: SAGE Publications.

Bowling, Ben, and James Sheptycki. 2015. Global Policing and Transnational Rule with Law. Transnational Legal Theory 6(1): 141-173.

Brodeur, Jean-Paul. 2010. The Policing Web. New York: Oxford University Press.

Busuioc, Madalina, Deirdre Curtin, and Martijn Groenleer. 2011. Agency Growth Between Autonomy and Accountability: The European Police Office as a 'Living Institution'. Journal of European Public Policy 18(6): 848-867.

84 Innes (2010a). 
Calcara, Giulio. 2018. Preventing the Misuse of interpol: A Study on the Legal Safeguards of the Organization. Nordic Journal of International Law 87(1): 56-78.

Cardwell, Paul James, and Tamara Hervey. 2016. Bringing the Technical into the Socio-Legal: The Methaphors of Law and Legal Scholarship of a Twenty-First Century European Union. In Exploring the 'Legal' in Socio-Legal Studies, ed. David Cowan and Daniel Wincott, 157-182. London: Palgrave.

Chang, Dae H. 1994. International Judicial Co-operation in Criminal Matters. International Journal of Comparative and Applied Criminal Justice 18(1-2): 141-195.

Choongh, Satnam. 2007. Doing Ethnographic Research: Lessons from a Case Study. In Research Methods for Law, ed. Mike McConville and Chui Wing Hong, 69-86. Edinburgh: Edinburgh University Press.

Cownie, Fiona. 2004. Legal Academics: Cultures and Identities. Oxford: Hart Publishing.

Cryer, Robert, Tamara Hervey, Bal Sokhi-Bulley, and Alexandra Bohm. 2011. Research Methodologies in EU and International Law. Oxford: Hart Publishing.

Deflem, Mathieu. 2002. Policing World Society: Historical Foundations of International Police Cooperation. New York: Oxford University Press.

Deflem, Mathieu. 2004a. Global Rule of Law or Global Rule of Law Enforcement? International Police Cooperation and Counterterrorism. The Annals of the American Academy of Political and Social Science 603(1): 240-251.

Deflem, Mathieu. 2004b. Social Control and the Policing of Terrorism: Foundations for a Sociology of Counterterrorism. The American Sociologist 35(2): 75.

Deflem, Mathieu. 2009. Interpol. In The Sage Dictionary of Policing, ed. Wakefield Alison and Fleming Jenny, 179-181. London: Sage Publications.

European Parliament. 2019a. Fact Sheets on the European Union: Police Cooperation. http://www. europarl.europa.eu/factsheets/en/sheet/156/police-cooperation.

European Parliament. 2019b. Fact Sheets on the European Union: Judicial Cooperation in Criminal Matters. http://www.europarl.europa.eu/factsheets/en/sheet/155/judicial-cooperation-in-crimi nal-matters.

Europol. 2017. Serious and Organised Crime Threat Assessment (SOCTA) 2017. https://www.europ ol.europa.eu/sites/default/files/documents/report_socta2017_1.pdf.

Europol. 2018a. About Europol. https://www.europol.europa.eu/about-europol.

Europol. 2018b. Internet Organised Crime Threat Assessment (IOCTA) 2018. https://www.europ ol.europa.eu/sites/default/files/documents/iocta2018.pdf.

Europol. 2019. EU Terrorism Situation \& Trend Report (Te-Sat) 2019. https://www.europol.europ a.eu/sites/default/files/documents/tesat_2019_final.pdf.

Fair Trials. 2013. Strengthening Respect for Human Rights, Strengthening Interpol. http://www.fairt rials.org/sites/default/files/publication_pdf/Strengthening-respect-for-human-rights-strengthen ing-INTERPOL5.pdf.

Fair Trials. 2018. Strengthening Interpol: An Update. https://www.fairtrials.org/publication/stren gthening-interpol-update\#glossary-of-key-terms-and-abbreviations.

Folami, Olakunle Michael, and Rachel Joan Naylor. 2017. Police and Cross-Border Crime in an Era of Globalisation: The Case of the Benin-Nigeria Border. Security Journal 30(3): 859-879.

General Secretariat of the Council. 2014. Conclusions of the 10th Annual Meeting of the National Experts on Joint Investigation Teams (25-26 June 2014, the Hague). http://www.eurojust. europa.eu/doclibrary/JITs/JITs\%20meetings/Conclusions\%20of\%20the \%2010th\%20Mee ting $\% 20$ of\% 20National $\% 20$ Experts $\% 20$ on\%20Joint\%20Investigation $\% 20$ Teams $/ 17115$ _2014-12-19_EN.pdf.

General Secretariat of the Council. 2017. Joint Investigation Teams Practical Guide. https://www.europ ol.europa.eu/sites/default/files/documents/jit-guide-2017-en.pdf.

Gerspacher, Nadia. 2008. The History of International Police Cooperation: A 150-Year Evolution in Trends and Approaches. Global Crime 9(1-2): 169-184.

Gerspacher, Nadia, and Veronique Pujas. 2013. International Police Organizations: The Missing Link to Effective Cooperation. In International Police Cooperation: Emerging Issues, Theory and Practice, ed. Lemieux Frédéric, 241-259. New York: Routledge.

Hall, Stephen. 2007. Researching International Law. In Research Methods for Law, ed. Mike McConville and Chui Wing Hong, 181-206. Edinburgh: Edinburgh University Press. 
Hodgson, Jacqueline, and Andrew Roberts. 2010. Criminal Process and Prosecution. In The Oxford Handbook of Empirical Legal Research, ed. Cane Peter and Kritzer Herbert, 64-95. Oxford: Oxford University Press.

Hughes, Bryn, Charles T. Hunt, and Jodie Curth-Bibb. 2013. Forging New Conventional Wisdom Beyond International Policing: Learning from Complex Political Realities. Leiden: Brill.

Innes, Martin. 2010a. The Art, Craft, and Science of Policing. In The Oxford Handbook of Empirical Legal Research, ed. Cane Peter and Kritzer Herbert, 11-36. Oxford: Oxford University Press.

Innes, Martin. 2010b. A 'Mirror' and a 'Motor': Researching and Reforming Policing in an Age of Austerity. Policing: A Journal of Policy and Practice 4(2): 127-134.

INTERPOL. 2018. Annual Report 2017. https://www.interpol.int/en/content/download/5258/file/Annua 1\%20Report\%202017-EN.pdf.

Jackson, John D., and Sarah J. Summers. 2012. The Internationalisation of Criminal Evidence: Beyond the Common Law and Civil Law Traditions. Cambridge: Cambridge University Press.

Joutsen, Matti. 2014. A View from the Trenches: the Reality of International Cooperation. In Handbook of Transnational Crime and Justice, ed. Reichel Philip and Albanese Jay, 419-424. Thousand Oaks, CA: SAGE Publications.

Jung, Jeyong, and Chang-Moo Lee. 2019. A New Law Enforcement Cooperation Model in Southeast Asia and an Examination of Its Global Application: A Korean Desk. Pacific Focus 34(1): 127-147.

Klabbers, Jan, and Åsa Wallendahl. 2011. Research Handbook on the Law of International Organizations. Helsinki: Edward Elgar Publishing.

Klosek, Jacqueline. 1999. The Development of International Police Cooperation within the EU and Third Party States: A Discussion of the Legal Bases of Such Cooperation and the Problems and Promises Resulting Thereof. American University International Law Review 14(3): 599-656.

Koskenniemi, Martti, and Päivi Leino. 2002. Fragmentation of International Law? Postmodern Anxieties. Leiden Journal of International Law 15(3): 553-579.

Lemieux, Frédéric. 2013. The Nature and Structure of International Police Cooperation: An Introduction. In International Police Cooperation: Emerging Issues, Theory and Practice, ed. Lemieux Frédéric, 1-24. New York: Routledge.

Lemon, Edward. 2019. Weaponizing Interpol. Journal of Democracy 30(2): 15-29.

Ling, Cheah Wui. 2010a. Mapping Interpol's Evolution: Functional Expansion and the Move to Legalization. Policing: A Journal of Policy and Practice 4(1): 28-37.

Ling, Cheah Wui. 2010b. Policing Interpol: The Commission for the Control of Interpol's Files and the Right to a Remedy. International Organizations Law Review 7(2): 375-404.

Marks, Monique. 2004. Researching Police Transformation: The Ethnographic Imperative. The British Journal of Criminology 44(6): 866-888.

Martha, Rutsel Silvestre J. 2010. The Legal Foundations of Interpol. Oxford: Hart Publishing.

McConville, Mike, and Chui Wing Hong. 2007. Introduction and Overview. In Research Methods for Law, ed. Mike McConville and Chui Wing Hong, 1-15. Edinburgh: Edinburgh University Press.

Mc Kenzie, Michael. 2017. Securitising Transnational Crime: The Political Drivers of Police Cooperation Between Australia and Indonesia. Policing and Society. https://doi.org/10.1080/10439 463.2017.1299734.

Mitsilegas, Valsamis. 2012. The Limits of Mutual Trust in Europe's Area of Freedom, Security and Justice: From Automatic Inter-State Cooperation to the Slow Emergence of the Individual. Yearbook of European Law 31(1): 319-372.

Nunzi, Alfredo. 2006. Les institutions de coopération pénale European Police Office - EUROPOL. Revue Internationale de Droit Pénal 77(1): 285-292.

Occhipinti, John D. 2003. The Politics of EU Police Cooperation: Toward a European FBI?, 2003. London: Lynne Rienner Publishers.

Occhipinti, John D. 2015. Still Moving Toward a European FBI? Re-Examining the Politics of EU Police Cooperation. Intelligence and National Security 30(2-3): 234-258.

Reiner, Robert. 2000. Police Research. In Doing Research on Crime and Justice, ed. Roy D. King and Emma Wincup, 205-235. Oxford: Oxford University Press.

Reitano, Tuesday, Troels Oerting, and Marcena Hunter. 2015. Innovations in International Cooperation to Counter Cybercrime: The Joint Cybercrime Action Taskforce. The European Review of Organised Crime 2(2): 142-154.

Riekmann, Sonja Puntscher. 2008. Security, Freedom and Accountability: Europol and Frontex. In Security Versus Justice? Police and Judicial Cooperation in the European Union, ed. Guild Elspeth and Geyer Florian, 19-34. London: Routledge. 
Sadoff, David A. 2016. Bringing International Fugitives to Justice: Extradition and Its Alternatives. New York: Cambridge University Press.

Savino, Mario. 2010. Global Administrative Law Meets Soft Powers: The Uncomfortable Case of Interpol Red Notices. New York University Journal of International Law and Politics 43: 263-336.

Sciarabba, Anthony L., and Christopher G. Sullivan. 2010. Transnational Crime and the Law: An Overview of Current Practices. In Police Practices in Global Perspective, ed. John A. Eterno and K.Das Dilip, 225-250. Lanham, Maryland: Rowman \& Littlefield Publishers.

Sheptycki, James. 2004. The Accountability of Transnational Policing Institutions: The Strange Case of Interpol. Canadian Journal of Law and Society/La Revue Canadienne Droit et Société 19(1): 107-134.

Sheptycki, James. 2017. Transnational Organization, Transnational Law and the Ambiguity of Interpol in a World Ruled with Law. Brill Research Perspectives in Transnational Crime 2-3: 65-86.

Thwaites, Nadine. 2006. EUROJUST: Beacon in EU Judicial Co-operation. Revue internationale de droit pénal 77(1): 293-298.

Ugelvik, Synnøve. 2019. Police Cooperation and Sovereignty in the EU: Norway's Lessons for Europe. London, New York: Routledge Press.

Van Gestel, Rob, Hans-W Micklitz, and Edward L. Rubin. 2017. Introduction. In Rethinking Legal Scholarship: A Transatlantic Dialogue, ed. Rob Van Gestel, Hans-W Micklitz, and Edward L. Rubin, 1-28. Cambridge: Cambridge University Press.

Watt, Gary. 2012. Comparison as Deep Appreaciation. In Methods of Comparative Law, ed. Pier Giuseppe Monateri, 82-103. Cheltenham: Edward Elgar Publishing.

Weigend, Thomas. 2006. Criminal Law and Criminal Procedure. In Elgar Encyclopedia of Comparative Law, ed. Jan M. Smits, 214-226. Cheltenham: Edward Elgar Publishing.

Wellens, Karel. 2002. Remedies Against International Organisations. New York: Cambridge University Press.

Wennström, Bo. 2013. In Search of a New Lens! In European Police and Criminal Law Co-operation, ed. Bergström Maria and Cornell Anna Jonsson, 179-184. Oxford: Hart Publishing.

Zabyelina, Yuliya. 2019. The Role of Major Intergovernmental Organizations and International Agencies in Combating Transnational Crime. In International and Transnational Crime and Justice, ed. Mangai Natarajan, 305-310. Cambridge: Cambridge University Press.

Zweigert, Konrad, and Hein Kötz. 1998. An Introduction to Comparative Law. New York: Oxford University Press.

Publisher's Note Springer Nature remains neutral with regard to jurisdictional claims in published maps and institutional affiliations. 